\title{
FOREIGN AFFAIRS
}

The Capital Myth: The Difference between Trade in Widgets and Dollars

Author(s): Jagdish Bhagwati

Reviewed work(s):

Source: Foreign Affairs, Vol. 77, No. 3 (May - Jun., 1998), pp. 7-12

Published by: Council on Foreign Relations

Stable URL: http://www.jstor.org/stable/20048871

Accessed: $23 / 01 / 2013$ 15:40

Your use of the JSTOR archive indicates your acceptance of the Terms \& Conditions of Use, available at http://www.jstor.org/page/info/about/policies/terms.jsp

JSTOR is a not-for-profit service that helps scholars, researchers, and students discover, use, and build upon a wide range of content in a trusted digital archive. We use information technology and tools to increase productivity and facilitate new forms of scholarship. For more information about JSTOR, please contact support@jstor.org.

Council on Foreign Relations is collaborating with JSTOR to digitize, preserve and extend access to Foreign Affairs. 


\title{
The Capital Myth
}

\section{The Difference between Trade in Widgets and Dollars}

\author{
Fagdish Bhagmati
}

In the aftermath of the Asian financial crisis, the mainstream view that dominates policy circles, indeed the prevalent myth, is that despite the striking evidence of the inherently crisis-prone nature of freer capital movements, a world of full capital mobility continues to be inevitable and immensely desirable. Instead of maintaining careful restrictions, we are told, the only sensible course is to continue working toward unfettered capital flows; the favored solution is to turn the IMF even more firmly into an international lender of last resort that dispenses bailout funds to crisis-afflicted countries. The IMF took an important step in this direction at its annual meeting in Hong Kong last September, when the Interim Committee issued a statement virtually endorsing an eventual move to capital account convertibility - which means that you and I, nationals or foreigners, could take capital in and out freely, in any volume and at any time- for IMF members. The obligations originally listed in 1944 in the Articles of Agreement, on the other hand, included only "avoidance of restrictions on payments for current transactions" and did not embrace capital account convertibility as an obligation or even a goal.

This is a seductive idea: freeing up trade is good, why not also let capital move freely across borders? But the claims of enormous benefits from free capital mobility are not persuasive. Substantial gains have been asserted, not demonstrated, and most of the payoff can be obtained by direct equity investment. And even a richer IMF with attendant changes in its methods of operation will probably not rule out crises or reduce their costs significantly. The myth to the contrary has been created by what one might christen the Wall Street-Treasury complex, following in the footsteps of President Eisenhower, who had warned of the military-industrial complex.

\section{CAPITAL MOBILITY IDEOLOGY}

Until the Asian crisis sensitized the public to the reality that capital movements could repeatedly generate crises, many assumed that free capital mobility among

Jagdish Bhagwati is Arthur Lehman Professor of Economics at Columbia University. He was the Economic Policy Adviser to the Director-General of the General Agreement on Tariffs and Trade from 1991 to 1993. 


\section{Jagdish Bhagwati}

all nations was exactly like free trade in their goods and services, a mutual-gain phenomenon. Hence restricted capital mobility, just like protectionism, was seen to be harmful to economic performance in each country, whether rich or poor. That the gains might be problematic because of the cost of crises was not considered.

However, the Asian crisis cannot be separated from the excessive borrowings of foreign short-term capital as Asian economies loosened up their capital account controls and enabled their banks and firms to borrow abroad. In 1996, total private capital inflows to Indonesia, Malaysia, South Korea, Thailand, and the Philippines were $\$ 93$ billion, up from $\$ 41$ billion in 1994. In 1997, that suddenly changed to an outflow of $\$ 12$ billion. Hence it has become apparent that crises attendant on capital mobility cannot be ignored.

Although it is conceded that this downside exists, many claim that it can be ameliorated, if not eliminated, and that free capital mobility's immense advantages can be enjoyed by all. Conservatives would do this by letting the markets rip, untended by the IMF, which could then be sidelined or even disbanded. Liberals would do it instead by turning the IMF into the world's lender of last resort, dispensing funds during crises with several sorts of conditions, and overseeing, buttressing, and managing the world of free capital mobility.

To understand why neither of these modifications is enough, it is necessary to understand why the original version of the myth, which has steadily propelled the IMF into its complacent and dangerous moves toward the goal of capital account convertibility, was just that. True, economists properly say that there is a correspondence between free trade in goods and services and free capital mobility: interfering with either will produce efficiency losses. But only an untutored economist will argue that, therefore, free trade in widgets and life insurance policies is the same as free capital mobility. Capital flows are characterized, as the economic historian Charles Kindleberger of the Massachusetts Institute of Technology has famously noted, by panics and manias.

Each time a crisis related to capital inflows hits a country, it typically goes through the wringer. The debt crisis of the 198 os cost South America a decade of growth. The Mexicans, who were vastly overexposed through short-term inflows, were devastated in 1994. The Asian economies of Thailand, Indonesia, and South Korea, all heavily burdened with short-term debt, went into a tailspin nearly a year ago, drastically lowering their growth rates. Sure enough, serious economic downturns and crises can arise even when governments are not particularly vulnerable due to short-term borrowing: macroeconomic mismanagement in Japan has restrained its growth rate for nearly seven years now, and Japan is still a net lender of capital. But it is a non sequitur to suggest, as the defenders of free capital mobility do, that this possibility somehow negates the fact that short-term borrowings under free capital mobility will be, and have been, a source of considerable economic difficulty.

\section{DOWNSIZING GAINS}

When a crisis hits, the downside of free capital mobility arises. To ensure that capital returns, the country must do everything it can to restore the confidence of those who have taken their money out. This typically means raising interest rates, as the IMF has required of Indonesia. Across Asia this

[8] FOREIGN AFFAIRS - Volume 77 No.3 


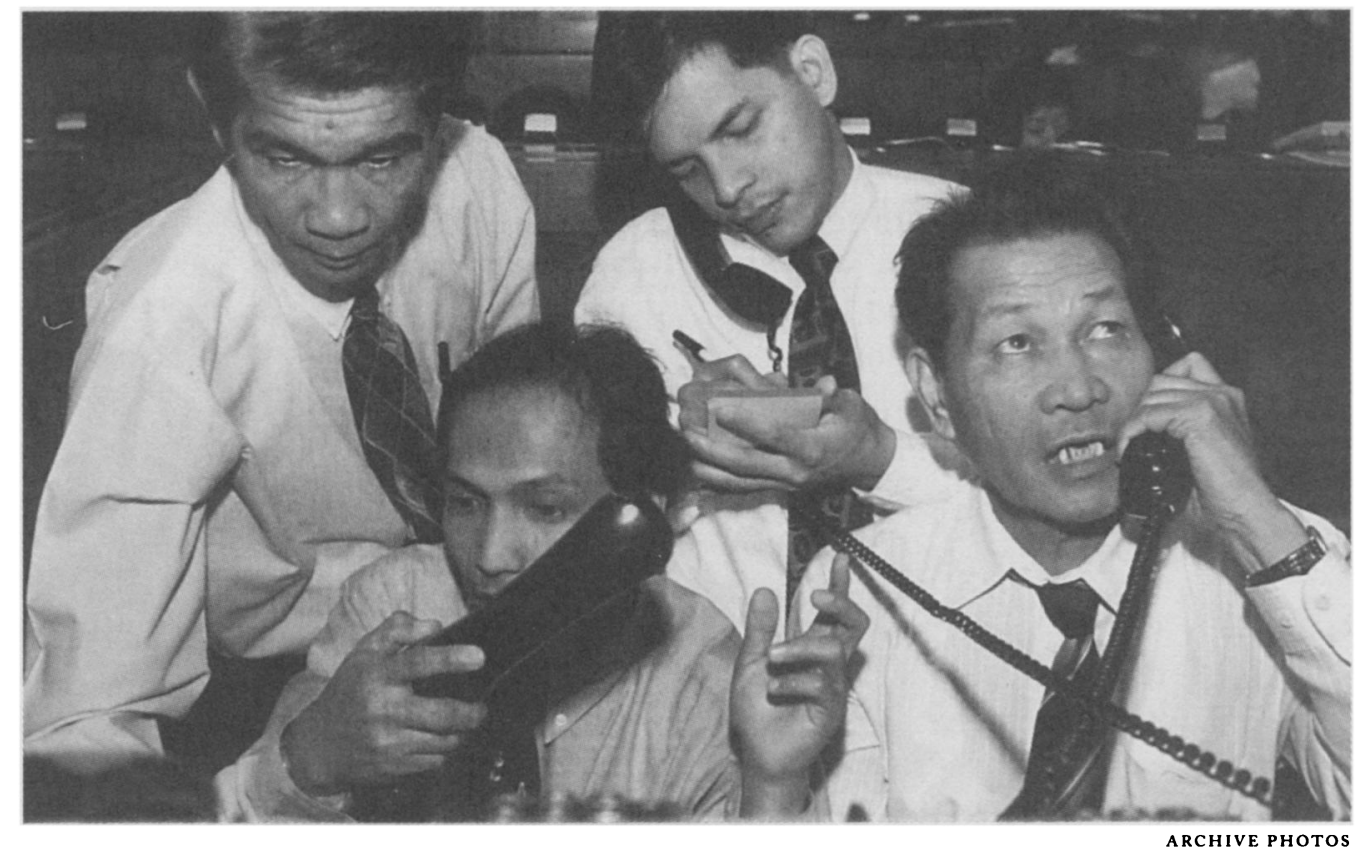

Crisis on line one: Filipino traders react as Manila'sstock market tumbles, October 28, 1997

has decimated firms with large amounts of debt. It also means having to sell domestic assets, which are greatly undervalued because of the credit crunch, in a fire sale to foreign buyers with better access to funds. (Economists have usually advised the exact opposite in such depressed circumstances: restricting foreign access to a country's assets when its credit, but not that of others, has dried up.) Thus, Thailand and South Korea have been forced to further open their capital markets, even though the short-term capital inflow played a principal role in their troubles in the first place.

Besides suffering these economic setbacks, these countries have lost the political independence to run their economic policies as they deem fit. That their independence is lost not directly to foreign nations but to an IMF increasingly extending its agenda, at the behest of the U.S. Congress, to invade domestic policies on matters of social policy —as with the 1994 Sanders-Frank Amendment, which seeks to attach labor standards conditions to any increase in bailout funds-is small consolation indeed.

Thus, any nation contemplating the embrace of free capital mobility must reckon with these costs and also consider the probability of running into a crisis. The gains from economic efficiency that would flow from free capital mobility, in a hypothetical crisis-free world, must be set against this loss if a wise decision is to be made.

None of the proponents of free capital mobility have estimated the size of the gains they expect to materialize, even leaving out the losses from crises that can ensue. For free trade, numerous studies have measured the costs of protection. The overwhelming majority of trade economists judge the gains from free

FORE IGN AFFAIR S · May/June 1998 


\section{Jagdish Bhagwati}

trade to be significant, coming down somewhere between Paul Krugman's view that they are too small to be taken seriously and Jeffrey Sachs' view that they are huge and cannot be ignored. But all we have from the proponents of capital mobility is banner-waving, such as that of Bradford De Long, the Berkeley economist and former deputy assistant secretary for economic policy in the Clinton administration:

So now we have all the benefits of free flows of international capital. These benefits are mammoth: the ability to borrow abroad kept the Reagan deficits from crushing U.S. growth like an egg, and the ability to borrow from abroad has enabled successful emerging market economies to double or triple the speed at which their productivity levels and living standards converge to the industrial core.

\section{And of Roger C. Altman, the invest-} ment banker, who served in the Treasury Department under Presidents Clinton and Carter:

The worldwide elimination of barriers to trade and capital ... have created the global financial marketplace, which informed observers hailed for bringing private capital to the developing world, encouraging economic growth and democracy. ${ }^{1}$

These assertions assume that free capital mobility is enormously beneficial while simultaneously failing to evaluate its crisis-prone downside. But even a cursory glance at history suggests that these gains may be negligible. After all, China and Japan, different in politics and sociology as well as historical experience, have registered remarkable growth rates without capital account convertibility. Western Europe's return to prosperity was also achieved without capital account convertibility. Except for Switzerland, capital account liberalization was pretty slow at the outset and did not gain strength until the late 1980s, and some European countries, among them Portugal and Ireland, did not implement it until the early 1990 .

Besides, even if one believes that capital flows are greatly productive, there is still an important difference between embracing free portfolio capital mobility and having a policy of attracting direct equity investment. Maybe the amount of direct foreign investment that a country attracts will be reduced somewhat by not having freedom of portfolio capital flows, but there is little evidence for this assertion. Even then such a loss would be a small fraction of the gains from having a pro-foreign investment strategy.

\section{A WALL STREET-TREASURY COMPLEX}

That brings us to the myth that crises under capital account convertibility can be eliminated. We have, of course, heard this assertion before as each crisis has been confronted, and then we have been hit by yet another one. Like cats, crises have many lives, and macroeconomists, never a tribe that enjoyed a great reputation for getting things right or for agreeing among themselves, have been kept busy adding to the taxonomy of crises and their explanations. None of the solutions currently propounded can

${ }^{1}$ Bradford De Long, “What's Wrong with Our Bloody Economies?” January 11, 1998, from his World Wide Web page, http://econ161.berkeley.edu/; Roger C. Altman, "The Nuke of the 9o's," The New York Times Magazine, March 1, 1998, p. 34.

[10] FOREIGN AFFAIRS - Volume 77 No.3 


\section{The Capital Myth}

really rid the system of free capital mobility of instability.

Thus, while no one can disagree with Secretary of the Treasury Robert Rubin's contention that reform of banking systems around the world will help, few should agree with him that it will eliminate the crises that unregulated capital flows inherently generate. Nor can the abolition of the IMF and its lender of last resort bailouts be the magic bullet: there were crises before the writer Walter Bagehot invented this function for domestic central banks in the nineteenth century. Nor can making the IMF more powerful kill the crises or give it the nonexistent macroeconomic wisdom to manage them at least cost when they arise.

In short, when we penetrate the fog of implausible assertions that surrounds the case for free capital mobility, we realize that the idea and the ideology of free trade and its benefits - and this extends to the continuing liberalization of trade in goods and financial and other services at the World Trade Organization-have, in effect, been hijacked by the proponents of capital mobility. They have been used to bamboozle us into celebrating the new world of trillions of dollars moving about daily in a borderless world, creating gigantic economic gains, rewarding virtue and punishing profligacy. The pretty face presented to us is, in fact, a mask that hides the warts and wrinkles underneath.

The question, then, is why the world has nonetheless been moving in this direction. The answer, as always, reflects ideology and interests - that is, lobbies. The ideology is clearly that of markets. The steady move away from central planning, overregulation, and general overreach in state intervention toward letting markets function has now reached across many sectors and countries. This is indeed all to the good and promises worldwide prosperity. But this wave has also lulled many economists and policymakers into complacency about the pitfalls that certain markets inherently pose even when they were understood in the classroom. Free capital mobility is just one example of this unwarranted attitude. Indeed, Stanley Fischer, the deputy managing director of the IMF, admitted in a February appearance on the Charlie Rose show on PBS that he had underestimated the probability of such crises arising in a world of capital mobility.

But interests have also played a central role. Wall Street's financial firms have obvious self-interest in a world of free capital mobility since it only enlarges the arena in which to make money. It is not surprising, therefore, that Wall Street has put its powerful oar into the turbulent waters of Washington political lobbying to steer in this direction. Thus, when testifying before the Senate Foreign Relations Committee on South Asia in March 1995, right after the Mexican peso crisis, I was witness to the grilling of Undersecretary of Commerce Jeffrey E. Garten on why India's financial system was not fully open to U.S. firms. To his credit, Garten said that this was not exactly a propitious time for the United States to pressure India in this direction.

Then again, Wall Street has exceptional clout with Washington for the simple reason that there is, in the sense of a power elite à la C. Wright Mills, a definite networking of like-minded luminaries among the powerful institutions-Wall Street, the Treasury Department, the State Department, the IMF, and the World Bank most prominent among them. Secretary Rubin comes from Wall Street; Altman went from Wall Street to 
the Treasury and back; Nicholas Brady, President Bush's Secretary of the Treasury, is back in finance as well; Ernest Stern, who has served as acting president of the World Bank, is now managing director of J.P. Morgan; James Wolfensohn, an investment banker, is now president of the World Bank. One could go on.

This powerful network, which may aptly, if loosely, be called the Wall Street-Treasury complex, is unable to look much beyond the interest of Wall Street, which it equates with the good of the world. Thus the IMF has been relentlessly propelled toward embracing the goal of capital account convertibility. The Mexican bailout of 1994 was presented as necessary, which was true. But so too was the flip side, that the Wall Street investors had to be bailed out as well, which was not. Surely other policy instruments, such as a surcharge, could have been deployed simultaneously to punish Wall Street for its mistakes. Even in the current Asian crisis, particularly in South Korea, U.S. banks could all have been forced to the bargaining table, absorbing far larger losses than they did, but they were cushioned by the IMF acting virtually as a lender of first, rather than last, resort.

And despite the evidence of the inherent risks of free capital flows, the Wall Street-Treasury complex is currently proceeding on the self-serving assumption that the ideal world is indeed one of free capital flows, with the IMF and its bailouts at the apex in a role that guarantees its survival and enhances its status. But the weight of evidence and the force of logic point in the opposite direction, toward restraints on capital flows. It is time to shift the burden of proof from those who oppose to those who favor liberated capital.

\section{Foreign Affairs}

\section{Associate Editor}

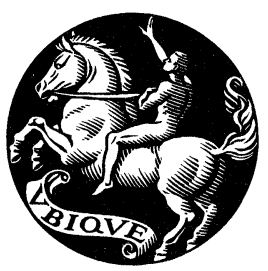

Foreign Affairs is looking for an Associate Editor. The ideal candidate would have exemplary writing skills, editing experience, and some background in international affairs.

An associate editor participates in all editorial phases of the magazine: prospecting for authors, reviewing manuscripts, editing copy, and preparing the layout with desktop publishing equipment. Some familiarity with QuarkXPress software is preferable, but not required.

Applications will be accepted throughout the summer. Requirements: résumé, five writing samples, and three letters of recommendation.

Address package to:

MANAGING EDITOR FOREIGN AFFAIRS 58 EAST 68 TH STREET NEW YORK, NY 10021

TEL: 212.434 .9502

FAX: 212.861 .1849

[12] FOREIGN AFFAIRS V Volume 77 No.3 